Article

\title{
Regional Urbanization and Knowledge-Intensive Business Activities (KIBS): An Example of Small and Medium-Sized Cities in the Greater Stuttgart Region (Germany)
}

\author{
Madeleine Wagner *(D) and Anna Growe $\mathbb{D}$ \\ Department of Geography, Heidelberg University, 69120 Heidelberg, Germany; anna.growe@uni-heidelberg.de \\ * Correspondence: madeleine.wagner@uni-heidelberg.de; Tel.: +49-6221-545-565
}

Received: 26 November 2019; Accepted: 17 December 2019; Published: 19 December 2019

check for updates

\begin{abstract}
The objective of this paper is to understand the role of small and medium-sized cities as economic locations, and as potential anchor locations, in grounding processes of regional urbanization in the knowledge economy. Based on quantitative occupational data, the deconcentration processes of knowledge-intensive business activities are analyzed for the Greater Stuttgart Region in southern Germany. The way in which the different knowledge bases used in knowledge-intensive business activities influence spatial patterns of economic activity in the surrounding area of the core city, including small and medium-sized towns, is discussed. The knowledge bases differentiated in this paper are analytical, synthetic and symbolic knowledge.
\end{abstract}

Keywords: small and medium-sized towns; knowledge economy; reurbanization

\section{Introduction}

Up until the 1990s, a phase of intense suburbanization processes could be observed in Germany. In particular, population patterns changed in favor of suburban areas and at the expense of core cities [1]. However, since the 2000s, a new role for cities-a renaissance of the city, in effect-has been discussed, using the term 'reurbanization' [2-6]. Reurbanization can be understood either as cities growing -in contrast to a shrinking or slower-growing hinterland-or as positive net migration changes, people favoring cities at the expense of their hinterlands [1,7].

The discussion about a renaissance of the city is not only being driven by changing population patterns, but also by changing patterns of economic activities due to the rising knowledge-based economy. As a result of the increasing importance of knowledge-intensive services, and creative and research-intensive industries, working locations in core cities are gaining importance [8]. The increasing importance of cities as economic locations in the knowledge economy can be explained by both the small space requirements of knowledge-processing activities in comparison to manufacturing opportunities (for learning, observation and knowledge exchange) and by their good transport infrastructure (for creating face-to-face interactions beyond local contacts) [9-11]. Additionally, also density is an important factor influencing - in particular-the settlement of knowledge-intensive business services in agglomerations [12] (p. 1), [13].

The increasing importance of cities due to the rising knowledge economy has so far been discussed primarily in the context of large cities and metropolitan regions $[14,15]$. From this research perspective, only a few outstanding cities, and the regions surrounding them, have been considered. One reason for this is that particular occupations, that require intensive and continuous exchange and contact with others, also tolerate the higher costs in large cities [16]. This focus has developed because large cities have been identified as important locations of knowledge-based economic activities [14,17-21]; 
for example, in the case of matching workers and jobs [22], as well as other "micro-foundations, based on sharing, matching and learning mechanisms" [12] (p. 1), [13].

Although some studies have highlighted that it is not only large cities that act as hubs for knowledge-intensive activities, but also their surrounding conurbations [23], there are only a few studies in the literature that focus on the role of small and medium-sized cities in the knowledge economy [24-27]. While it is evident that cities are becoming increasingly important, both as places to live and work in (i.e., the renaissance of the city), it is unclear how small cities can benefit from these developments. Small and medium-sized cities have so far been a neglected category in spatial research. Only recently have small and medium-sized cities been taken into account in reurbanization research [3], and their role as locations for population and economic activities is still controversial.

In some case studies, small and medium-sized cities have been discussed, mainly in the context of shrinkage and peripheralization [28]. Other studies have identified demographic reurbanization processes in favor of small and medium-sized cities [3], which are caused by 'spill-over effects' due to high rents in large cities see also [29-31].

Against this background, the question arises, to what extent can small and medium-sized cities benefit as places of work, given that large cities with high rents and traffic problems also have major agglomeration disadvantages [32-34]. Following this argument, small and medium-sized cities could benefit as alternative economic locations because they have fewer agglomeration disadvantages (costs, traffic problems) than larger cities, and have more agglomeration advantages (labor pool, training and transport infrastructure) than peripheral areas [35]. Initial observations that large cities, in particular, are becoming less attractive for highly skilled workers and that small and medium-sized cities are more likely to benefit at the same time were published as an industrial report for the USA [34]. Additionally, it is argued that highly skilled workers "who require fewer and less intense interactions will locate in regions that are further away from metropolitan regions" [16] (p. S13), [36].

To understand the role of small and medium-sized cities as economic locations in the knowledge economy, we focus on spatial changes in an economically strong and innovative region in southern Germany. In this paper, we analyze the different spatial patterns of knowledge-intensive business activities in the Greater Stuttgart Region at the level of municipal associations. A municipal association can be (a) an affiliation of several municipalities to form a local authority with self-administration, or (b) an independent local authority with directly elected representatives of the people. This varies from state to state. Municipal associations thus represent a larger territorial unit than municipalities and serve as a frame of reference in the following analysis, as the data are only accessible down to the level of municipal associations. To understand the changes in the region, we examine whether small and medium-sized cities gained in importance as locations for knowledge-based economic activities between 1999 and 2011, and differentiate between three types of knowledge-based economic activities.

The paper is structured as follows: In Section 2, we deal with theoretical approaches relating to knowledge-intensive business activities and spatial proximity. Section 3 presents and explains the case study region-the Greater Stuttgart Region. We also introduce the methods and data used in the paper. In Section 4, we provide our empirical results and answer our research questions. The discussion in Section 5 summarizes the findings with regard to changing spatial patterns of knowledge-intensive economic activities in small and medium-sized cities in a metropolitan region, using the example of the Greater Stuttgart Region.

\section{Theoretical Approaches: Knowledge-Intensive Business Activities and Spatial Proximity}

How to structure different knowledge-intensive business activities is an ongoing topic of discussion. One possibility is to do this according to their use of knowledge in the economic process. In this case, a differentiation can be made between activities generating knowledge, activities transforming knowledge, activities organizing transactions, and activities transforming knowledge in standardized products $[37,38]$. Another possibility is to differentiate the activities according to their main knowledge base. 
According to Asheim and Gertler [39], Asheim, Coenen and Vang [10], and Gertler [40], three knowledge bases can be distinguished, which simultaneously refer back to the distinction between implicit and explicit knowledge: (a) analytical knowledge; (b) synthetic knowledge; (c) symbolic knowledge.

(a) Analytical knowledge plays an important role in activities in which scientific knowledge has great importance. Scientific knowledge, in this context, refers to formalizable knowledge; that is, knowledge based on formal deductive models and scientific laws [40]. The activities in which analytical knowledge plays a central role mainly include research and development. Here, the development of new products happens through systematic research and the exchange of knowledge in the form of scientific articles or patents [19,41]. Innovations that are based on analytical knowledge are-in contrast to innovations with other knowledge bases-planned and intentional [41]. Nevertheless, the process is not exclusive or per-se linear-even if the communication follows a more standardized model—and much information is based on codified knowledge, such as protocols or reports [41].

(b) Synthetic knowledge is mainly used in activities where innovations are gained through the application, and new combinations, of already existing knowledge [19,40]. The production of new synthetic knowledge is mainly determined by the search for solutions to specific problems. Such searches are based on the intensive interaction between the customers and providers of knowledge, through "learning by doing, using and interacting" [41] (p. 1091). Research plays a minor role. New synthetic knowledge is thus produced more inductively than deductively, and its production is more context-bound than the production of analytical knowledge [19].

(c) Symbolic knowledge has strong aesthetic, emotional and semiotic characteristics. According to Asheim, Coenen and Vang [10], such knowledge is mainly produced and used in activities in the growing cultural industries (media, music, fashion, design, etc.). The creation of symbolic knowledge focuses on the production of a new idea or a new symbol. Although symbolic knowledge can be embedded in material products (e.g., in furniture or clothing), its economic value stems from the meaning of the symbol, the design or the idea, for both consumers and users; that is, through the intangible character of the symbolic knowledge. Symbolic knowledge is therefore strongly context-specific, since the interpretation of symbols, designs or cultural artifacts depends on the understanding and norms of specific social groups [10]. The use and production of symbolic knowledge can thus vary widely between different places [19,41].

These different knowledge bases are also associated with different demands on proximity in the knowledge-generating processes. Since face-to-face interaction plays a particularly important role in innovations based on problem-solving processes, synthetic knowledge is more context-bound than, for example, analytical knowledge [42]. This learning process during collaboration usually takes place "by just being there" [41] (p. 1091) and without a fixed goal (buzz) [43]. The social and cognitive dimensions of proximity are decisive here. The different actors in a team must have a certain basic understanding (cognitive proximity) in order to be able to exchange knowledge, despite their heterogeneous professional backgrounds. Each actor must be willing and open to communicate with, and learn from, the other/s (social proximity). The interaction, and thus the other proximity dimensions, can be supported and strengthened through the colocation of the actors and their geographical proximity. Even institutional agreements, such as shared values and norms, can contribute to the success of an innovation and simplify the communication process among the actors. Thus, for innovations based on synthetic knowledge, the trust and interaction between different actors plays an important role.

Analytical knowledge, on the other hand, is based more on implicit knowledge. In order to correctly interpret and understand the codified information passed on, there must be a certain cognitive proximity between the actors $[41,42,44,45]$. Having access to the information and knowledge of the other participating actors is helpful, and thus organizational proximity plays a role. Especially in the 
first phases of knowledge production, geographical and social proximity between the actors has a positive effect on interaction, and can sustainably simplify the innovation process [41,46].

Since the interpretation of symbols, designs or cultural artifacts depends on the understanding and norms of specific social groups [10], (temporary) geographical and social proximity-which is expressed as trust between actors-can be especially decisive in the success of innovation with symbolic knowledge content. Institutional proximity, and thus knowledge of the values and needs of the clients as well as the legal framework, can also be decisive. Furthermore, a certain basic understanding among the various actors and users should be reached, especially at the local level (cognitive proximity) [41].

\section{Materials and Methods}

\subsection{Case Study: The Greater Stuttgart Region}

The case study presented in this paper is that of the Greater Stuttgart Region. As Greater Stuttgart Region, we have combined Stuttgart as the core city and all directly adjacent urban-rural regions based on the category of urban-rural region. Three indicators are used to define urban-rural regions: (a) population share in large and medium-sized cities, (b) population density in the urban-rural region, and (c) population density in the urban-rural region excluding large and medium-sized cities [47]. This region is located in southwestern Germany, in Baden-Wurttemberg. In Germany, Baden-Wurttemberg plays a leading role when viewed from demographic, economic and labor-market perspectives. After North Rhine-Westphalia and Bavaria, Baden-Wurttemberg is Germany's most populous and largest state (see Table 1) [48,49]. Baden-Wurttemberg is one of the most innovative regions in Europe, and ranks far above the German average [50]. The unemployment rate in Baden-Wurttemberg has been fallen continuously since 2009 , currently standing at 3.2\%-the second lowest rate in Germany, behind Bavaria [51].

Table 1. Area and inhabitants.

\begin{tabular}{cccc}
\hline Länder & Area (2017) & Inhabitants (2018) & $\begin{array}{c}\text { Unemployment Rate } \\
\text { (November 2019) }\end{array}$ \\
\hline Bavaria & $70,542 \mathrm{~km}^{2}$ & 13,077 thousand & $2.7 \%$ \\
Lower Saxony & $47,710 \mathrm{~km}^{2}$ & 7982 thousand & $4.8 \%$ \\
Baden-Wurttemberg & $35,748 \mathrm{~km}^{2}$ & 10,070 thousand & $3.1 \%$ \\
North Rhine-Westphalia & $34,112 \mathrm{~km}^{2}$ & 17,933 thousand & $6.4 \%$ \\
Brandenburg & $29,654 \mathrm{~km}^{2}$ & 2512 thousand & $5.4 \%$ \\
Mecklenburg-Western & $23,394 \mathrm{~km}^{2}$ & 1610 thousand & $6.7 \%$ \\
Pomerania & $21,116 \mathrm{~km}^{2}$ & 6266 thousand & $4.2 \%$ \\
Hesse & $20,454 \mathrm{~km}^{2}$ & 2208 thousand & $6.6 \%$ \\
Saxony-Anhalt & $19,858 \mathrm{~km}^{2}$ & 4085 thousand & $4.2 \%$ \\
Rhineland-Palatinate & $18,450 \mathrm{~km}^{2}$ & 4078 thousand & $5.0 \%$ \\
Saxony & $16,202 \mathrm{~km}^{2}$ & 2143 thousand & $4.9 \%$ \\
Thuringia & $15,804 \mathrm{~km}^{2}$ & 2897 thousand & $4.9 \%$ \\
Schleswig-Holstein & $2571 \mathrm{~km}^{2}$ & 991 thousand & $6.0 \%$ \\
Saarland & $891 \mathrm{~km}^{2}$ & 3645 thousand & $7.6 \%$ \\
Berlin & $755 \mathrm{~km}^{2}$ & 1841 thousand & $6.0 \%$ \\
Hamburg & $419 \mathrm{~km}^{2}$ & 683 thousand & $9.8 \%$ \\
Bremen & \multicolumn{2}{c}{ Source: $[48,49,51]$} & \\
\hline
\end{tabular}

The Greater Stuttgart Region, in particular, is considered to be the most innovative and economically strong region in the state of Baden-Wurttemberg [52]. In terms of settlement structure, the region is characterized by small (5000 to 20,000 inhabitants) and medium-sized (20,000 to 100,000 inhabitants) cities (see Figure 1). This categorization was developed by the Federal Institute for Research on Building, Urban Affairs and Spatial Development [53], as well as by the categorization of the commuter 
areas and the municipal associations, and is widely used in Germany. Using this categorization here facilitates data comparison with other studies.

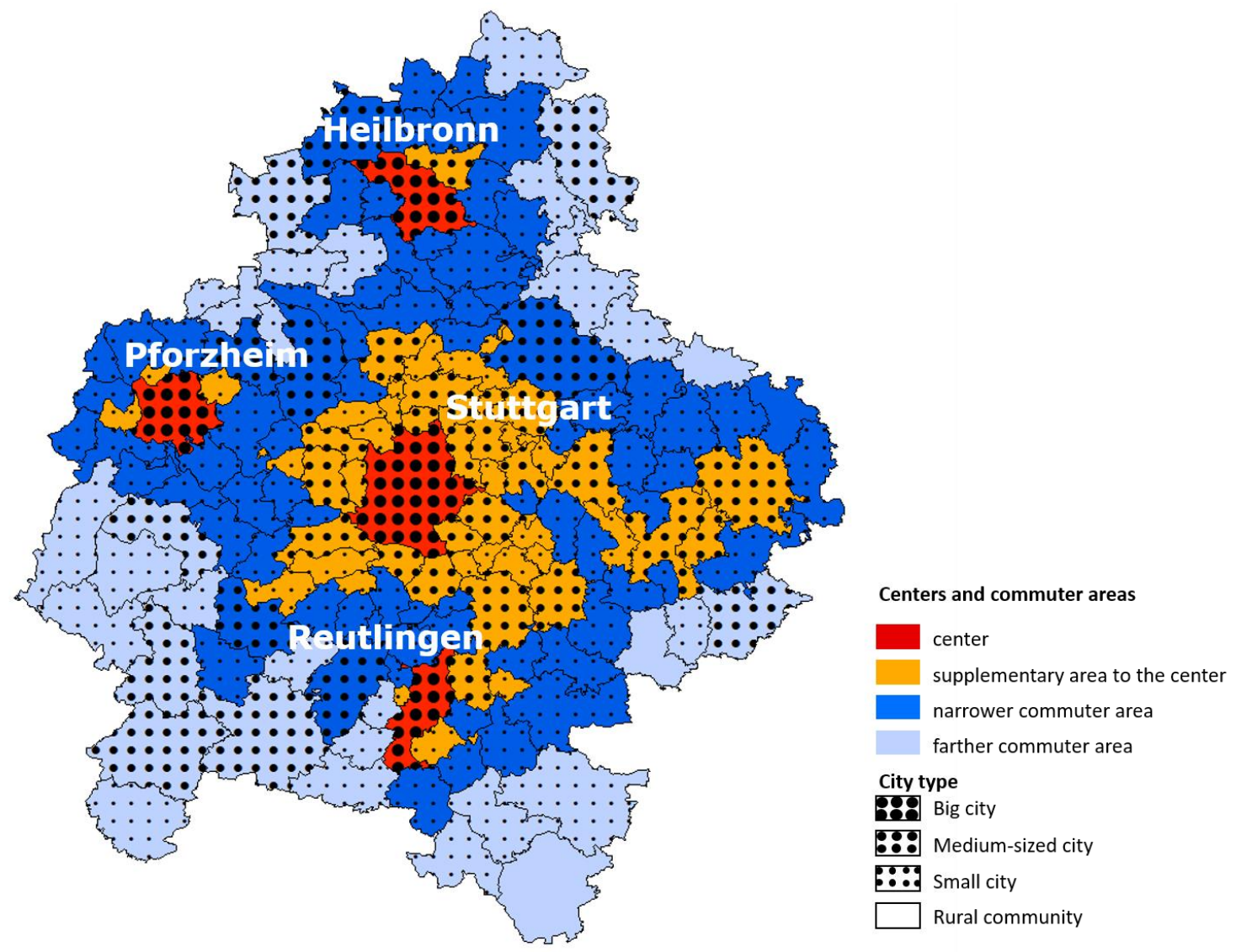

Figure 1. Greater Stuttgart Region and commuting areas.

Apart from the state capital, Stuttgart, there are only three large cities $(>100,000$ inhabitants) in the region-Heilbronn, Pforzheim and Reutlingen. The population distribution in the entire region reflects the settlement structure (see Figure 2). For these circumstances, the Greater Stuttgart Region can be described as a polycentric region. A dense network of cities and thus a polycentric structure of a region can contribute to offsetting agglomeration and size effects, for example of metropolises. Therefore, "the whole network of cities [can be] more than the sum of its parts" [54] (p. 765), [55,56].

In terms of economic structure, the Greater Stuttgart Region is dominated by automotive industries, engineering, information and communication technologies, and creative industries. Due to the strong automotive industry and the many suppliers located in the region, the structure of the entire Great Stuttgart Region is influenced [57] by the industry. 


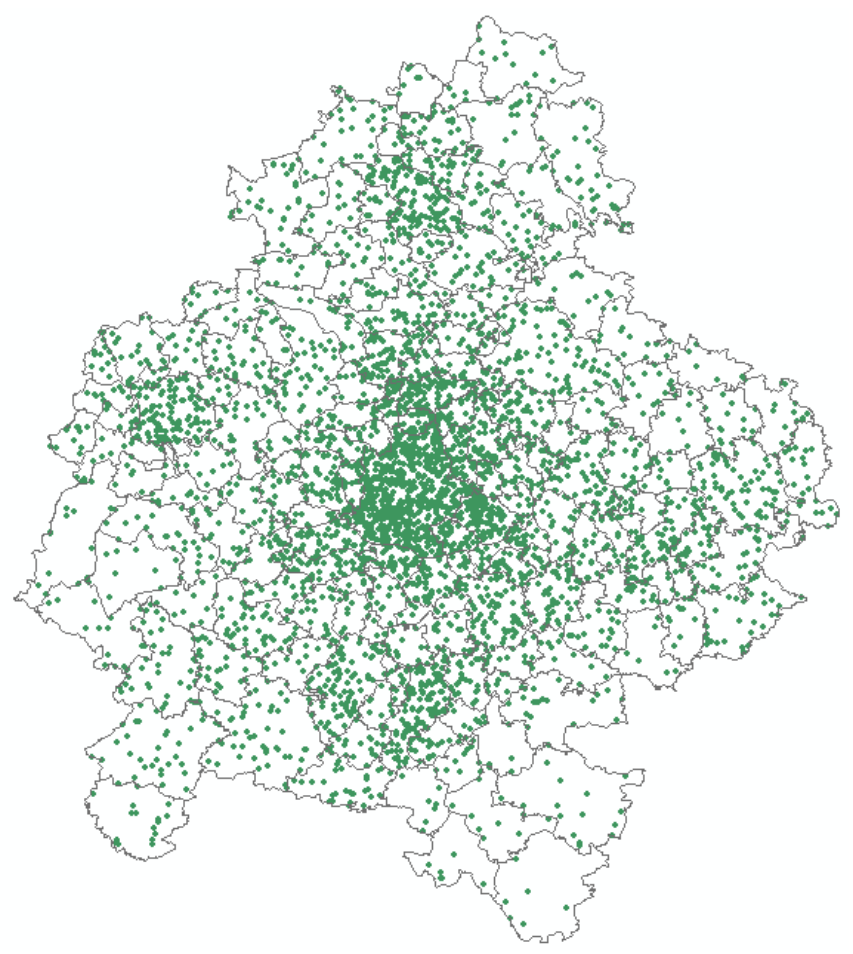

Figure 2. Population distribution in the Greater Stuttgart Region (1 dot $=700$ inhabitants).

\subsection{Data}

To operationalize spatial changes in functional economic patterns, occupational data from the Federal Employment Agency (FEA) in Germany is used. The data are available at the local administrative unit (LAU)-1 level, covering local administrative units aggregated into municipal associations. The data enables distinctions to be made between employees, subject to social insurance contributions according to occupational regulations and to the classification of occupations from 1988. This includes all employees subject to social security contributions (i.e., approximately $70 \%$ ). Not included are civil servants, self-employed persons, unpaid family workers and persons who work exclusively in so-called 'mini jobs'. The reference date for the survey is 31 December of each year.

The FEA's classification of occupational data groups occupations according to their similarity based on the activities, knowledge and skills that distinguish them [58]. The classification of employees according to their occupation, and not their qualifications, or the classification of the employer according to economic area, is used. This allows an analysis of functional patterns.

In the literature, knowledge-intensive business services are differentiated from research-intensive services [17,59,60], and from creative and cultural economic activities [61]; however, a final definition of what activities are categorized as knowledge-intensive business services is still missing. When selecting the occupational groups for this analysis, reference is made to the works of Growe [19] and Hall [62]. Hall [62] defined services as knowledge-intensive if they have an above-average proportion of highly qualified employees (more than 38.8\%). Based on this definition, Growe [19] differentiated 13 occupational groups (see Table 1) that could be aggregated into different functions (see Table 2).

The changes are analyzed based on data from 1999 up to 2011. Although data from more recent years is available, the data from before and after 2011 cannot be compared. This disadvantage has resulted from a newly introduced classification by the FEA, introduced in 2012, which reassigned occupational groups without providing the possibility for communication between the two categorizations. 
Table 2. Occupational classification of knowledge-intensive services.

\begin{tabular}{cc}
\hline Knowledge-Intensive Service Functions & KldB 1988 Code \\
\hline Accounting (ACC) & $753,771,772$ \\
Advertising (ADV) & $703,833,834,835,837$ \\
Architecture (ARC) & $603,604,623,624$ \\
Consulting (CON) & 752 \\
Consulting Engineering (CE) & $611,612,626$ \\
Data Management (DM) & 774 \\
Finance (FIN) & 691,692 \\
ICT (ICT) & 602,622 \\
Insurance (INS) & 693,694 \\
Law (LAW) & $811,812,813,814$ \\
Management (MAN) & 751 \\
Media (MED) & 821,822 \\
Real Estate (RE) & 704 \\
\hline
\end{tabular}

The classification of knowledge-intensive business activities into knowledge bases is strongly represented in the literature [42,63-68]. In classifying knowledge-intensive activities, we refer to the work of Growe [19]. Here, the occupational data for the knowledge functions is differentiated according to the three knowledge bases (see Table 3); however, it should be noted that the various functions are frequently not able to be separated accurately according to the knowledge bases. For example, activities in the fields of accounting and consulting are situated at the interface between analytical and synthetic knowledge (see also $[19,69])$.

Table 3. Assignment of occupational data to a knowledge base.

\begin{tabular}{ccc}
\hline Analytical Knowledge & Synthetic Knowledge & Symbolic Knowledge \\
\hline Architecture (ARC) & Accounting (ACC) & Advertising (ADV) \\
Consulting Engineering (CE) & Consulting (CON) & \\
Data Management (DM) & Finance (FIN) & \\
ICT (ICT) & Insurance (INS) & \\
& Law (LAW) & \\
& Management (MAN) & \\
& Real Estate (RE) & \\
\hline
\end{tabular}

Source: Based on Growe [19].

\subsection{Methods}

The aim of this paper is to identify spatial patterns of knowledge-intensive business services for the Greater Stuttgart Region, and thus to map concentration or deconcentration processes, with the aid of quantitative analyses. Percentage changes are calculated to show the shifting roles of locations within the region. Location quotients are used to calculate the relative concentration of services in the various municipal associations [69]. Therefore, the concentration of knowledge-intensive business services in a certain subregion (in this case, a municipal association) is set in relation to all employees in this occupational group in Germany. In municipal associations with values below 1, a below-average concentration of knowledge-intensive business activities was measured. Values greater than 1 describe an above-average allocation of employees in knowledge-intensive business activities.

\section{Results}

First of all, a general overview of the different knowledge bases in the Greater Stuttgart Region and in Germany overall is given. Then, the results for the Greater Stuttgart Region are presented and analyzed at the level of municipal associations. 


\subsection{Comparison Between the Greater Stuttgart Region and Germany as a Whole}

In order to understand the knowledge bases in the Greater Stuttgart Region, we compare the share of each knowledge base in the Greater Stuttgart Region with that in Germany as a whole at two points in time-1999 and 2011 (see Figure 3). The comparison shows that the Greater Stuttgart Region has a stronger focus on analytical knowledge at the expense of synthetic knowledge.

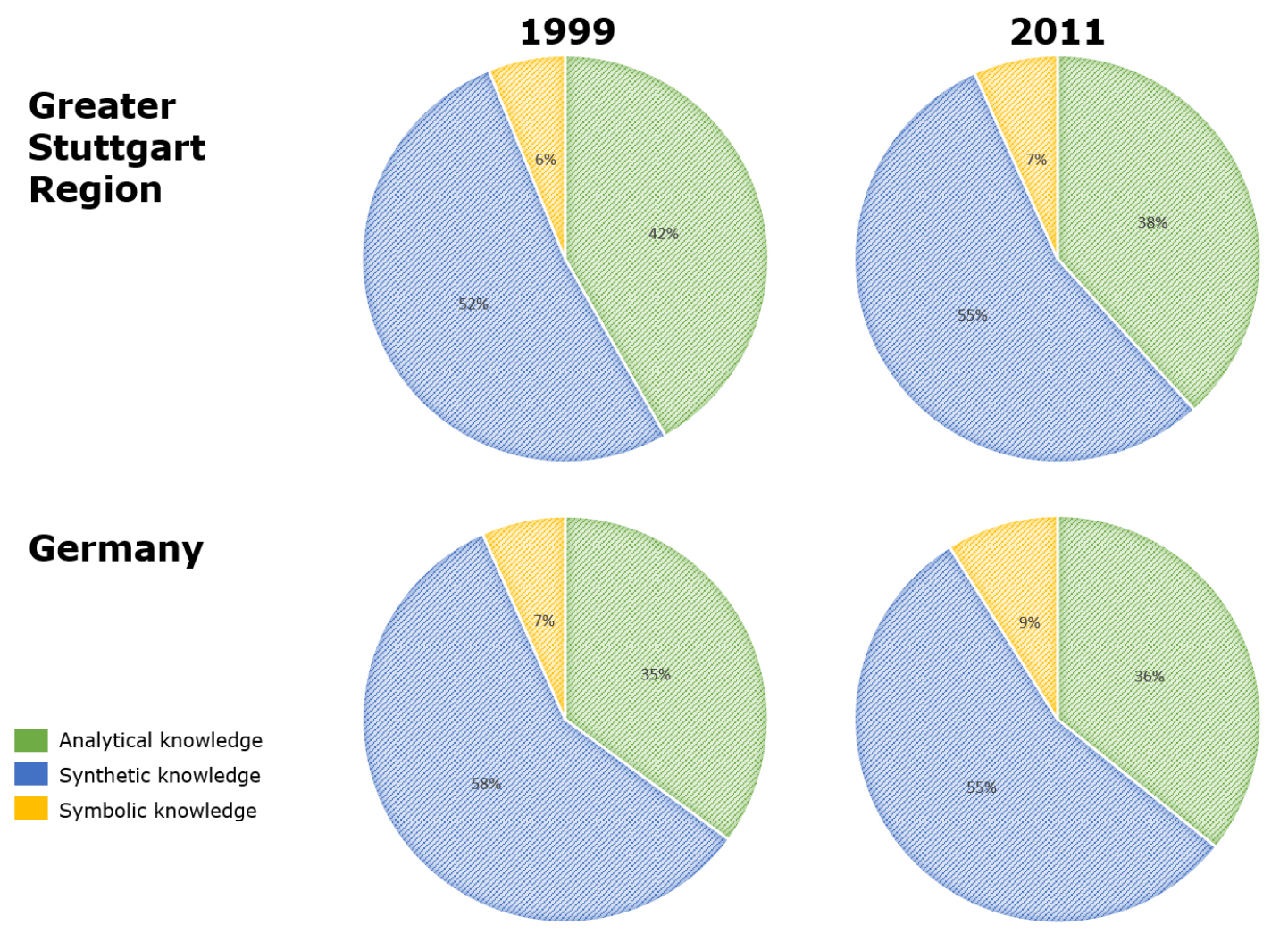

Figure 3. Comparison of knowledge bases between the Greater Stuttgart Region and Germany.

The comparison between the two time points suggests that the shares in the Greater Stuttgart Region approximate the shares in Germany over time. While Stuttgart still had an above-average share of analytical knowledge in 1999 (42\%), this share had declined to 38\% by 2011 (Germany in 2011: 36\%). The share of synthetic knowledge, on the other hand, increased slightly and-at 55\% in 2011-approximated the German average.

Figure 4 shows that, within the Greater Stuttgart Region in 1999, analytical knowledge was more deconcentrated than synthetic and symbolic knowledge. In the Greater Stuttgart Region, fewer than $20 \%$ of employees using analytical knowledge were located in Stuttgart and other big cities, and more than $35 \%$ of these employees were located in small cities and rural spaces. Of all the three knowledge bases, symbolic knowledge has a greater affinity with the city. More than $20 \%$ of employees using symbolic knowledge were located in Stuttgart and other big cities, and fewer than $25 \%$ of these employees were located in small cities and in rural spaces.

Figure 5 shows the percentage change in each knowledge base, standardized to the starting year of 1999, for Germany and the Greater Stuttgart Region over time (1999-2011). This comparison presents a different picture for each of the three knowledge bases. In terms of employees in the field of analytical knowledge, the Greater Stuttgart Region grew faster-year on year-than Germany, up to 2007. From 2002 to 2010, however, a weaker growth was visible. In 2007, the percentage annual growth in the number of employees using analytical knowledge in Germany exceeded the numbers for the Greater Stuttgart Region. This leads to the conclusion that there was a further alignment of employees using analytical knowledge between the Greater Stuttgart Region and Germany (see Figure 3). 


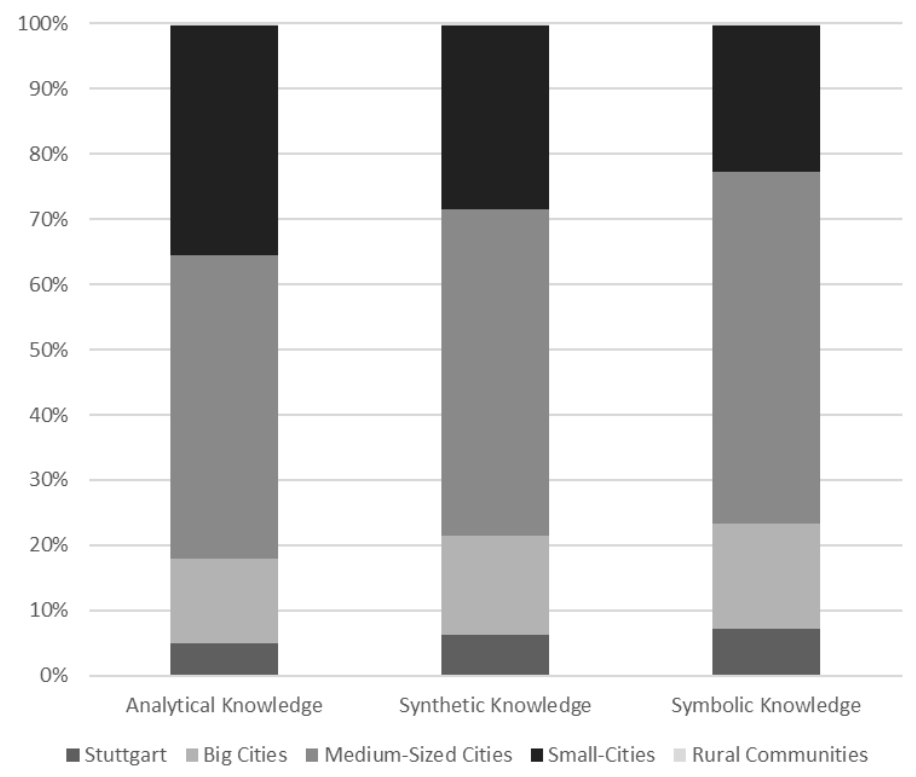

Figure 4. Share of the three knowledge bases in different spatial units in the Greater Stuttgart Region.

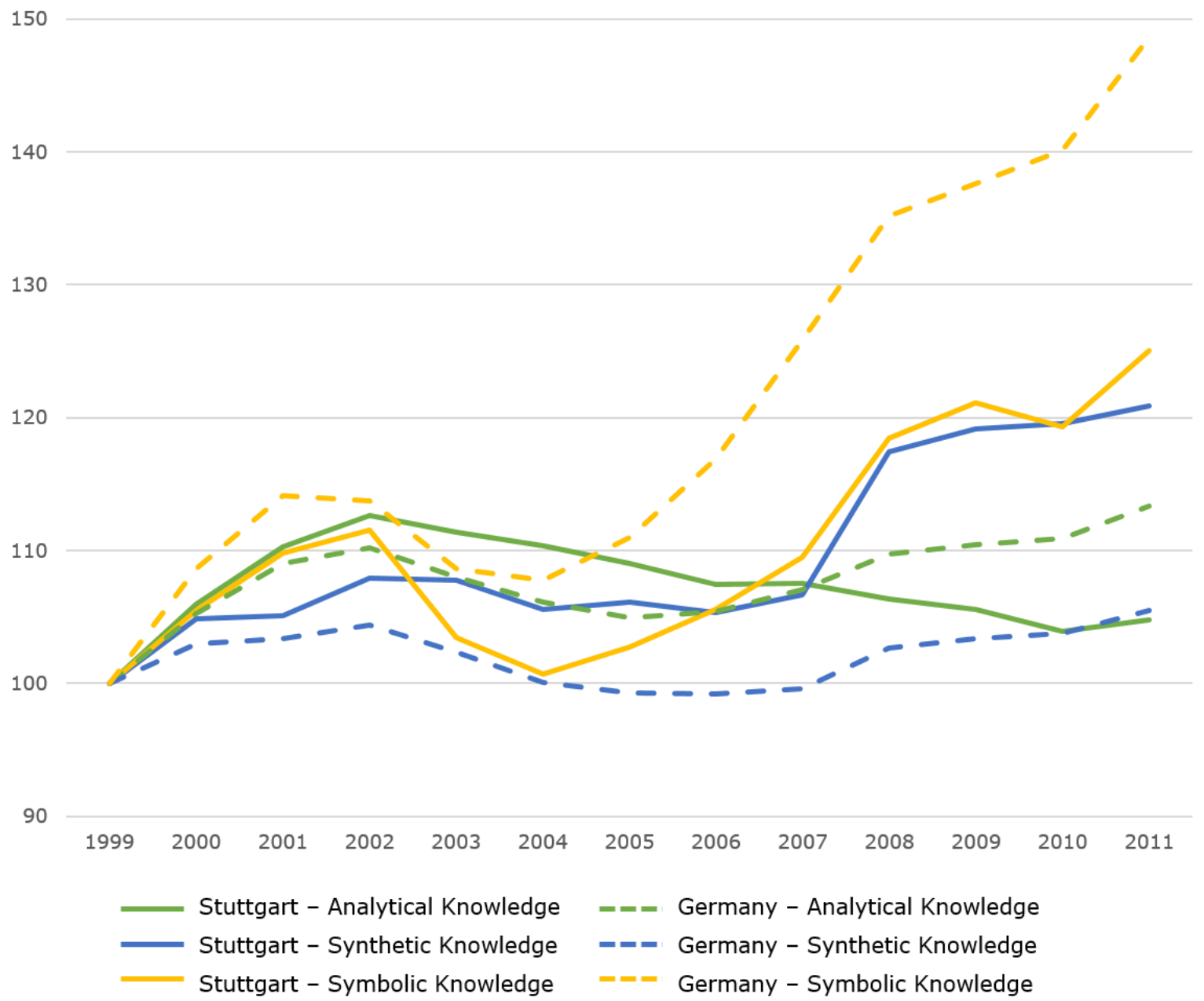

Figure 5. Development of the three knowledge bases in the Greater Stuttgart Region and Germany over time (1999-2011). 
In contrast, the percentage change in employees using synthetic knowledge in the Greater Stuttgart Region exceeded that in Germany from the beginning of 1999; this is also reflected in the pie charts in Figure 3. While the number of employees in Germany in 2011 was only a few percentage points higher than in 1999, the Greater Stuttgart Region experienced growth of over $20 \%$. In the area of symbolic knowledge, on the other hand, continuous growth was also emerging in the Greater Stuttgart Region, but, over the course of time, this remained well below the figure for Germany.

Previous studies in the field of the knowledge economy have mainly looked at metropoles or metropolitan regions as a whole, and not at the level of municipal associations. With this microgeographical approach, it is possible to take a closer look at both the core city (Stuttgart) and the major cities (e.g., Heilbronn, Pforzheim, Reutlingen) in the Greater Stuttgart Region, and the processes of reurbanization or deconcentration in the small and medium-sized cities in the environs of the larger cities.

Stuttgart is particularly suitable for this analysis, as it is one of the largest knowledge hubs in Germany [18]. In addition, previous analysis has shown that "the share of knowledge-based professions increased in the [Stuttgart] region but the share of connectivity declined. The importance of skilled workers can be explained by the fact that the Stuttgart region is characterized by high-tech industries. In contrast, service firms appear to be relatively less important in the Stuttgart region" [18] (p. 184).

Figure 6 refers to the area surrounding the Greater Stuttgart Region. It shows that, at the end of 2011, the percentage change in employees using all three knowledge bases was higher in the surrounding area than in the core city of Stuttgart. What is striking here is that, especially for employees using symbolic knowledge, the growth rate was already rising faster in the surrounding area than in the core city in 2003. It should be noted, however, that, due to the small number of employees using symbolic knowledge (see Figure 3), even slight rates of change are strongly reflected in comparisons with the other knowledge bases. The percentage growth rates in technical knowledge, on the other hand, were dominated by the core city up to 2010, and the shift to the surrounding countryside in the area of analytical knowledge did not occur until 2015. This trend becomes even clearer when comparing the surrounding countryside with the large cities in the surrounding countryside. Here, the percentage growth of all three knowledge bases in the surrounding area (small and medium-sized towns, as well as rural communities) had already exceeded that of the major cities (in this case, Reutlingen, Pforzheim and Heilbronn) in the surrounding area by a large margin since the starting year of 1999. From this, it can be concluded that the surrounding area in particular, and thus, above all, the small and medium-sized towns in the Greater Stuttgart Region, were becoming increasingly important as the locations of knowledge-intensive business activities. Thus, seen through the lens of percentage change, deconcentration processes were taking place in the surrounding area.

In order to consolidate this initial analysis, location quotients are analyzed in the following, at the level of municipal associations. 


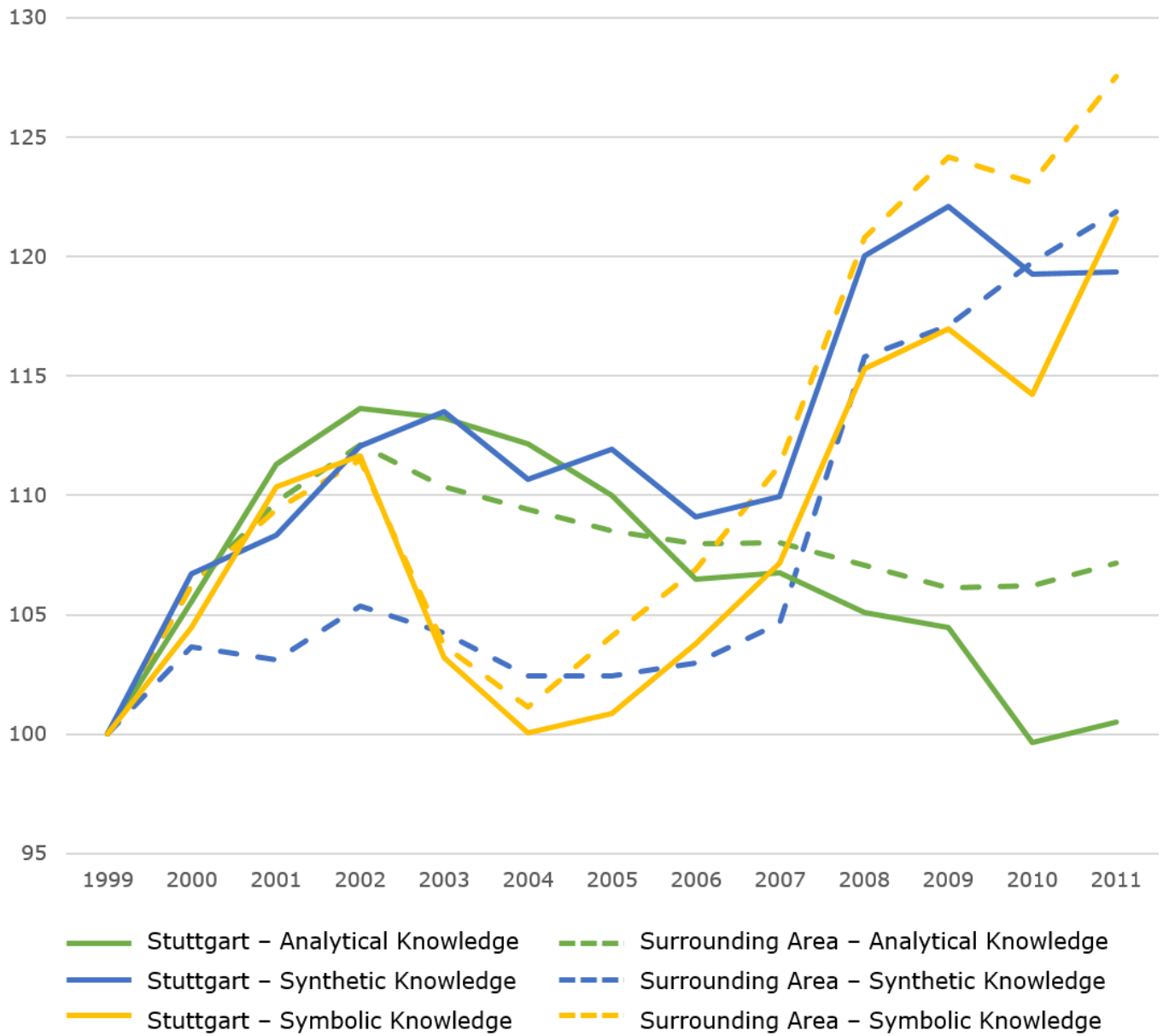

Figure 6. Development of the three knowledge bases in the area surrounding Stuttgart over time, including major cities and the core city of Stuttgart.

\subsection{Spatial Patterns of the Knowledge Bases}

In the case of analytical knowledge, the map illustrating the location quotients shows a relatively diverse picture in 2011, with the number of employees having continued to decenter into the surrounding area (especially in the Heilbronn region) (see Figure 7). Comparing this with Figure 6 shows that the stronger growth rates in the area of analytical knowledge since 2004 can also be confirmed by the location quotients. Analytical knowledge is more oriented towards the surrounding areas, although there is still a connection to the major cities. Municipal associations with a particularly high concentration of employees in the analytical knowledge field are located close to the centers around Stuttgart and Heilbronn. This goes hand in hand with the fact that analytical knowledge is based on implicit knowledge, where social proximity among actors is of particular importance. Geographical proximity, which also coincides with center affinity, can help, but is of secondary importance for occupations in the field of analytical knowledge.

Results from Growe [19] showed that, in 1999, the centers in particular showed above-average importance in the field of analytical knowledge, and that the deconcentration processes into the surrounding area took place in the period up to 2011. Our results also indicate deconcentration processes. This strengthens the hypothesis that the centers, in particular, were no longer gaining in importance for knowledge-intensive activities, in this case specifically for the analytical knowledge base see also [23]. 


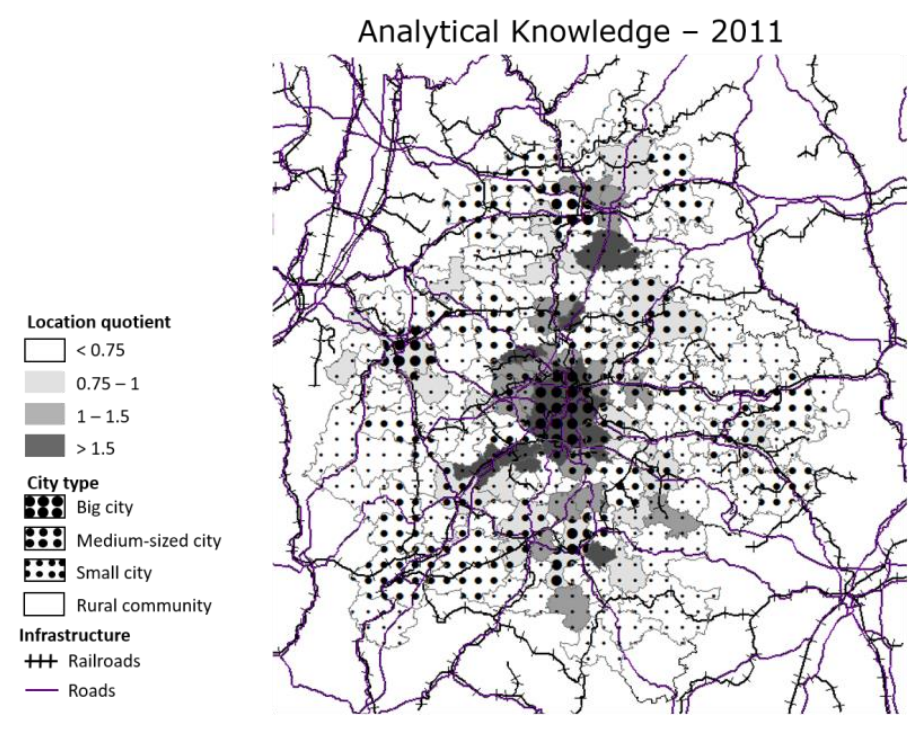

Synthetic Knowledge - 2011

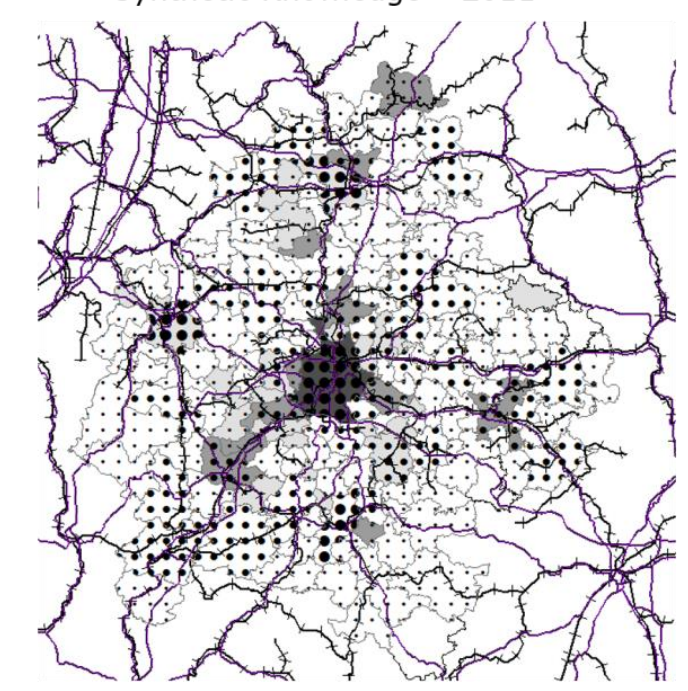

Symbolic Knowledge - 2011

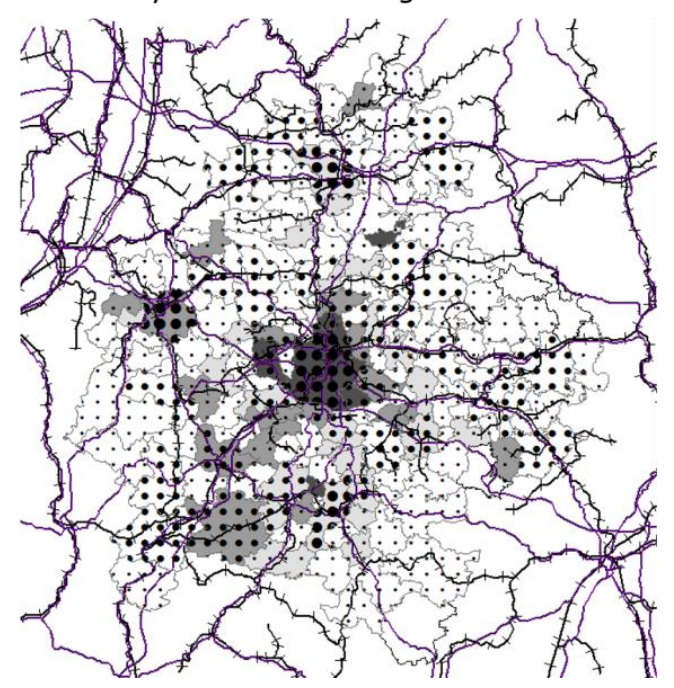

Figure 7. Location quotients for the three knowledge bases in 2011. 
Compared to the analytical knowledge base, synthetic knowledge presents a more homogenous picture by considering the location quotients from 2011. There are some municipality associations that have an above-average concentration of synthetic knowledge employees compared to the rest of the subspace (values between 1 and 1.5); however, no municipal associations with particularly large values stand out. In addition to Stuttgart and Heilbronn as big cities, some small towns also show an above-average concentration of synthetic knowledge. By combining the analysis of the location quotients with the results from Figure 5, it is confirmed that synthetic knowledge is still strongly concentrated in the core city of Stuttgart. However, the first steps of deconcentration processes can be identified, particularly in the hinterlands of core cities like Heilbronn and Reutlingen.

One reason for this is that colocation in particular can promote cooperation in the field of synthetic knowledge, since personal contact and interaction play important roles in this. Cognitive and social proximity - and thus trust-among the different actors involved in the process, are also promoted through colocation and thus employee concentration. Due to the importance of face-to-face interactions in this process, spatial proximity still plays a major role in employees using synthetic knowledge.

Looking at the third category of knowledge bases—symbolic knowledge-the location quotients in particular show a greater central and regional focus compared with synthetic knowledge. Especially to the south-west of Stuttgart, there are small and medium-sized towns that have a disproportionately high concentration of employees in the branches of media and advertising. It should be noted, however, that, due to the small number of employees in the field of symbolic knowledge, the concentration of employees in the different municipal associations is disproportionately high compared to those of the other knowledge bases. Thus, the location quotients of symbolic knowledge in particular must be considered separately and not in direct comparison.

Studies that have looked at Germany as a whole [19] have indicated that symbolic knowledge is mostly located in the core cities and not in the surrounding areas, but only in certain cities, such as Hamburg, Berlin, Essen, Munich and Baden-Baden, which are well known as media cities. There, a positive correlation with concentration processes in the core cities also became apparent $[19,70,71]$. In the case of the Greater Stuttgart Region, our analyses show that the surrounding area, especially, is gaining in importance for symbolic knowledge occupations. Based on Figure 6, the growth rates also show there has been a surplus in the surrounding area since 2003.

The Greater Stuttgart Region, which is best known for technical occupations and industrial production in Germany, does not represent a hub for symbolic knowledge (see also Figure 4). Therefore, it is notable that the small and medium-sized towns in the surrounding area can benefit especially from symbolic knowledge occupations, and that no strict affinity for the core city has prevailed, although a certain degree of regional concentration was found. This is also supported by the fact that (temporary) geographical and social proximity is particularly important for processes of symbolic knowledge, which, however, can also take place in smaller centers in the surrounding area.

\section{Discussion and Conclusions}

This paper aimed to understand the role of small and medium-sized cities as economic locations in the knowledge economy. Although some studies have highlighted that not only large cities act as hubs for knowledge-intensive activities, but also their surrounding conurbations [23], the role of small and medium-sized cities in the knowledge economy has been underexposed. In addition to that, most of the municipal associations in the Greater Stuttgart Region are located in the commuter area of one of these large cities (see Figure 1). This, in turn, supports our argument that small and medium-sized towns in the commuter area of large agglomerations should be examined especially with regard to their opportunities in the rising knowledge economy. For the analysis, we have drawn on the different knowledge bases of analytical, synthetic and symbolic knowledge, each of which has its own requirements for the different dimensions of (temporary) proximity and, thus, space and place.

Our analyses have shown that small and medium-sized towns in the environs of large cities can benefit not only from population growth [3], but also from new economic sectors. The Greater Stuttgart 
Region is known to be a region specializing in technical activities and industrial production, and has a distinctive polycentric structure. In the direct hinterland of the core city of Stuttgart are Reutlingen, Heilbronn and Pforzheim, three other large cities, some of which could also serve as anchor points for economic activities.

Our analyses have shown that analytical knowledge, in particular, dominates the region in comparison to Germany in 1999, but that the region gradually aligned towards the German average up to 2011.

Looking at the spatial patterns in the surrounding area in the Greater Stuttgart Region, the renaissance of the cities can also be observed in the small and medium-sized towns. Especially in the field of analytical knowledge, and in the immediate surroundings of the major cities, deconcentration processes have been taking place, the small and medium-sized cities benefiting from economic activities.

In contrast, occupations in synthetic knowledge are already relatively evenly distributed across the region, and there, only a slight tendency towards further deconcentration was found. This can be interpreted as a saturation effect.

Against the trend and previous studies, Stuttgart is presented as a growing region, in terms of symbolic knowledge. Whereas symbolic knowledge has elsewhere been described as having an affinity for the city, in the Greater Stuttgart Region, it is located in hubs in the surrounding area. One explanation for this is that Stuttgart has a relatively small share of occupations using the symbolic knowledge base, and thus even small changes in the number of employees can be seen in the analysis as disproportionate increases, for example.

Based on the previous findings we suggest differentiating three research implications. To understand the role of small and medium sized cities further research should account for possible path dependencies of the respective regions and the regions' economic structure compared to neighboring regions and the national economic structure, the relation of small and medium sized cities to the next large city (monocentric structured region or polycentric structured region), and the urban affinity of the occupations located in the respective small and medium sized cities and their region.

In sum, it can be stated that the agglomeration itself, as well as polycentric structures of a region, are particularly important for small and medium-sized towns in order to play an economic role in the knowledge society. With this argumentation, we agree with [26]. Policy implications have to take into account the local structure of the region, in the case of Stuttgart for example the dominance of the automotive industry, which influences the whole region economically and therefore also the settlement of the different knowledge bases. Due to these particularities, local policy implications have to be specialized "to strengthen their local autonomy" [26] (p. 31) and to successfully position the region in the knowledge economy as well.

To substantiate the findings of this pilot study, first, further regions need to be examined, with regard to the impact of the knowledge economy on small and medium-sized cities. Second, from a policy and planning perspective, it is necessary to shed light on the different regional preconditions and possible policy implications that support the hinterland of conurbations in monocentric regions as well. In addition, with regard to policy implications, discussions must also be held as to the extent to which local or supra-regional policies can bring advantages for the respective region [26]. This includes an estimation about the potential attractiveness of specific small- and medium-sized cities for various occupations, depending on their urban affinity (the higher the urban affinity of an occupation, the higher the need for large agglomerations). Third, it is useful to analyze both the demographic and economic developments in these regions in order to examine the extent to which small and medium-sized towns can be regarded as dormitory towns or as places to live and work. This leads to further questions in the field of spatial planning, particularly mobility and infrastructure planning.

Author Contributions: Conceptualization, A.G.; methodology, M.W.; validation, M.W.; formal analysis, M.W.; resources, M.W.; data curation, M.W.; writing—original draft preparation, M.W.; writing-review and editing, A.G.; visualization, M.W.; supervision, A.G. All authors have read and agreed to the published version of the manuscript. 
Funding: This research received no external funding.

Conflicts of Interest: The authors declare no conflict of interest.

\section{References}

1. Osterhage, F.; Kaup, S. Reurbanisierung als neue Phase der Stadtentwicklung? Eine Analyse der Bevälkerungsund Beschäftigungsentwicklung in Deutschland 1999 bis 2009. In Schwerpunkt. Stadt und Religion; Pohlan, J., Glausauer, H., Hannemann, C., Pott, A., Eds.; Verlag Barbara Budrich: Opladen, Germany, 2012; pp. 125-141.

2. Brake, K. Reurbanisierung-Intedependenzen zum Strukturwandel. In Reurbanisierung: Materialität und Diskurs in Deutschland; Brake, K., Herfert, G., Eds.; VS Verlag für Sozialwissenschaften: Wiesbaden, Germany, 2012; pp. 22-33.

3. Münter, A.; Osterhage, F. Trend Reurbanisierung? Analyse der Binnenwanderungen in Deutschland 2006 bis 2015. In Studie für die Bertelmanns Stiftung; 2018; Available online: https://www.bertelsmannstiftung.de/fileadmin/files/Projekte/74_Wegweiser-Kommune/Reurbanisierung_2018_final.pdf (accessed on 17 December 2019).

4. Brake, K.; Herfert, G. Reurbanisierung: Materalität und Diskurs in Deutschland; VS Verlag für Sozialwissenschaften: Wiesbaden, Germany, 2012.

5. Glaeser, E. Triumph of the City: How Our Greatest Invention Makes Us Richer, Smarter, Greener, Healthier and Happier; Penguin Books: London, UK, 2011.

6. Ehrenhalt, A. The Great Inversion and the Future of the American City; Knopf: New York, NY, USA, 2013.

7. Matthes, G. Zur Quantifizierung von Reurbanisierungstendenzen. Raumforsch. Raumordn. 2014, 72, 323-336. [CrossRef]

8. Growe, A.; Münter, A. Die Renaissance der großen Städte. Geogr. Rundsch. 2010, 62, 54-59.

9. Bathelt, H.; Malmberg, A.; Maskell, P. Clusters and knowledge: Local buzz, global pipelines and the process of knowledge creation. Prog. Hum. Geogr. 2004, 82, 31-56. [CrossRef]

10. Asheim, B.; Coenen, L.; Vang, J. Face-to-face buzz, and knowledge bases: Sociospatial implications for learning, innovation, and innovation policy. Environ. Plan. C Gov. Policy 2007, 25, 655-670. [CrossRef]

11. Shearmeen, F.; Arentze, T.; Timmermans, H. Dynamics of face-to-face social interaction frequency. Role of accessibility, urbanization, changes in geographical distance and path dependence. J. Transp. Geogr. 2014, 34, 211-220. [CrossRef]

12. Duranton, G.; Puga, D. Micro-Foundations of Urban Agglomeration Economies; 2003; Available online: https: //diegopuga.org/papers/urbanagg.pdf (accessed on 17 December 2019).

13. Carlino, G.; Chatterjee, S.; Hunt, R. Matching and Learning in Cities: Urban Density and the Rate of the Invention; Working Paper No. 04-16/R; 2005; Available online: http://ftp.zew.de/pub/zew-docs/veranstaltungen/inno_ patenting_conf/CarlinoChatterjeeHunt.pdf (accessed on 17 December 2019).

14. Kujath, H.J. Reurbanisierung des Wissens—zur Herausbildung von Metropolregionen unter dem Einfluss der Wissensökonomie. In Reurbanisierung: Materialität und Diskurs in Deutschland; Brake, K., Herfert, G., Eds.; VS Verlag für Sozialwissenschaften: Wiesbaden, Germany, 2012; pp. 216-238.

15. Growe, A. Knoten in Netzwerken wissensintensiver Dienstleistungen. Eine empirische Analyse des polyzentralen deutschen Städtesystems. Ph.D. Thesis, Technische Universität Dortmund, Dortmund, Germany, 2012.

16. Shearmur, R. Are cities the font of innovation? A critical review of the literature on cities and innovation. Cities 2012, 29, S9-S18. [CrossRef]

17. Lüthi, S.; Thierstein, A.; Goebel, V. Intra-firm and extra-firm linkages in the knowledge economy: The case of the emerging mega-city region of Munich. Glob. Netw. 2010, 10, 114-137. [CrossRef]

18. Growe, A.; Blotevogel, H.H. Knowledge Hubs in the German Urban System: Identifying Hubs by Combining Networks and Territorial Perspectives. Raumplan. Raumordn. 2011, 69, 175-185. [CrossRef]

19. Growe, A. Raummuster unterschiedlicher Wissensformen. Der Einfluss von Transaktionskosten auf Konzentrationsprozesse wissensorienter Dienstleister im deutschen Städtesystem. Raumforsch. Raumordn. 2012, 70, 175-190. [CrossRef]

20. Growe, A. Where do KIBS workers work in Germany? Shifting patterns of KIBS employment in metropoles, regiopoles and industrialised hinterlands. Erdkunde 2016, 70, 201-215. [CrossRef] 
21. Taylor, P.J.; Derudder, B.; Faulconbridge, J.; Hoyler, M.; Ni, P. Advanced Producer Service Firms as Strategic Networks, Global Cities as Strategic Places. Econ. Geogr. 2014, 90, 267-291. [CrossRef]

22. Andersson, F.; Burgess, S.; Lane, J.I. Cities, matching and the productivity gains of agglomeration. J. Urban Econ. 2007, 61, 112-128. [CrossRef]

23. Growe, A. Knowledge Hubs in the Polycentric German Urban System. Between Concentration Processes and Conurbation Dynamics. In Hub Cities in the Knowledge Economy. Seaports, Airports, Brainports; Conventz, S., Derudder, B., Thierstein, A., Witlox, F., Eds.; Ashgate Publishing Limited: London, UK, 2014.

24. Dijkstra, L.; Garcilazo, E.; McCann, P. The Economic Performance of European Cities and City Regions: Myths and Realities. Eur. Plan. Stud. 2013, 21, 334-354. [CrossRef]

25. Meili, R.; Mayer, H. Small and medium-sized towns in Switzerland: Economic heterogeneity, socioeconomic performance and linkages. Erdkd 2017, 71, 313-332. [CrossRef]

26. Kaufmann, D.; Meili, R. Leaves in the wind? Local policies of small and medium-sized towns in metropolitan regions. Eur. Plan. Stud. 2018, 27, 21-41. [CrossRef]

27. Meili, R. The influence of small town context on access to external knowledge. Entrep. Reg. Dev. 2019, 9, 826-841. [CrossRef]

28. Bojarra-Becker, E.; Franke, T.; Zur Nedden, M. Herausforderungen von Klein-und Mittelstädten. Fokus: Schrumpfung und Peripherisierung, Difu-Papers; Deutsches Institut für Urbanistik gGmbH: Berlin, Germany, 2017.

29. Aring, J. Bodenpreise und Raumentwicklung. Geogr. Rundsch. 2005, 57, 28-34.

30. Hamm, R.; Jäger, A.; Keggenhoff, K. Facetten der Reurbanisierung. Das Beispiel Mönchengladbach. Standort Z. Angew. Geogr. 2017, 41, 93-98. [CrossRef]

31. Meijers, E.J.; Burger, M.J. Stretching the concept of "borrowed size". Urban Stud. 2015, 54, 269-291. [CrossRef]

32. Burger, M.J.; Meijers, E.J.; Hoogerbrugge, M.M.; Tresserra, J.M. Borrowed Size, Agglomeration Shadows and Cultural Amenities in North-West Europe. Eur. Plan. Stud. 2014, 23, 1090-1109. [CrossRef]

33. Cardoso, R.V.; Meijers, E.J. Secondary Yet Metropolitan? The Challenges of Metropolitan Integration for Second-Tier Cities. Plan. Theory Pract. 2017, 18, 616-635. [CrossRef]

34. Florida, R. Talent May be Shifting away from Superstar Cities. Available online: www.citylab.com (accessed on 22 October 2019).

35. Meijers, E.; van der Wouw, D. Struggles and strategies of rural regions in the age of the "urban triumph". J. Rural Stud. 2019, 66, 21-29. [CrossRef]

36. Growe, A. Buzz at Workplaces as Knowledge-Intensive Service Production: Spatial Settings of Temporary Spatial Proximity. Eur. Urban Reg. Stud. 2019, 26, 434-448. [CrossRef]

37. Kujath, H.J. Die Rolle der Wissensökonomie in der globalen Arbeitsteilung. In Wissensbasierte Dienstleister in Metropolräumen; Heinelt, H., Kujath, H.J., Eds.; Verlag Barbara Budrich: Opladen, Germany, 2007; pp. $23-44$.

38. Kujath, H.J.; Zillmer, S. (Eds.) Räume der Wissensökonomie: Implikationen für das deutsche Städtesystem; LIT-Verlag: Münster, Germany, 2010.

39. Asheim, B.T.; Gertler, M.S. The Geography of Innovation: Regional Innovation Systems. In The Oxford Handbook of Innovation; Fagerberg, J., Mowery, D.C., Nelson, R.R., Eds.; Oxford University Press: Oxford, UK, 2007.

40. Gertler, M.S. Buzz without Being There? Communities of Practice in Context. In Community, Economic Creativity, Organization; Amin, A., Roberts, J., Eds.; Oxford University Press: Oxford, UK, 2008; pp. $203-226$.

41. Mattes, J. Dimensions of Proximity and Knowledge Bases: Innovation between spatial and non-spatial factors. Reg. Stud. 2012, 46, 1085-1099. [CrossRef]

42. Rutten, R. Beyond proximities. The socio-spatial dynamics of knowledge creation. Prog. Hum. Geogr. 2017, 41, 159-177. [CrossRef]

43. Growe, A. Die Gatewayfunktion-Von Verkehrsinfrastruktur zu Knoten im Netz? In Schneller, öfter, weiter? Perspektiven der Raumentwicklung in der Mobilitätsgesellschaft; Knapstein, Y., Meng, R., Ruppenthal, K., Schmitz-Veltin, A., Zakrzewski, P., Eds.; 2011; pp. 44-55. Available online: http://nbn-resolving.de/urn:nbn: de:0156-37176 (accessed on 25 October 2019).

44. Gertler, M.S. Tacit knowledge and the economic geography of context or the undefinable tacitness of being (there). J. Econ. Geogr. 2003, 3, 75-99. [CrossRef]

45. Howells, J.R.L. Tacit Knowledge, Innovation and Economic Geography. Urban Stud. 2002, 49, 871-884. [CrossRef] 
46. Boschma, R.A. Proximity and Innovation: A Critical Assessment. Reg. Stud. 2005, 39, 61-74. [CrossRef]

47. Federal Institute for Research on Building, Urban Affairs and Spatial Development (BBSR). Laufende Raumbeobachtung. Raumabgrenzungen. Stadt-Land-Regionen. Siedlungsstrukturtyp. Available online: https:/www.bbsr.bund.de/BBSR/DE/Raumbeobachtung/Raumabgrenzungen/deutschland/regionen/ StadtLandRegionen_Typen/StadtLandRegionen_Typen.html (accessed on 26 October 2019).

48. Statista Research Department. Einwohnerzahl der Bundesländer in Deutschland 2018. Available online: https://de.statista.com/statistik/daten/studie/71085/umfrage/verteilung-der-einwohnerzahl-nachbundeslaendern/ (accessed on 25 October 2019).

49. Statista Research Department. Fläche der deutschen Bundesländer 2017. Available online: https://de. statista.com/statistik/daten/studie/154868/umfrage/flaeche-der-deutschen-bundeslaender/ (accessed on 23 October 2019).

50. Baden-Württemberg Statistisches Landesamt. Innovationsindex 2018 für die Kreise und Regionen in Baden-Württemberg. Sechs Kreise in der Spitzengruppe mit Indexwerten über 50 Punkten. Available online: https://www.statistik-bw.de/Presse/Pressemitteilungen/2018290 (accessed on 1 November 2019).

51. Statista Research Department. Arbeitslosenquote in Deutschland nach bundesländern. Available online: https:/de.statista.com/statistik/daten/studie/36651/umfrage/arbeitslosenquote-in-deutschland-nachbundeslaendern/ (accessed on 1 November 2019).

52. Institut für Angewandte Wirtschaftsforschung (IAW). Fraunhofer-Institut für System-und Innovationsforschung ISI. ZEW-Leibniz-Zentrum für Europäische Wirtschaftsforderung. Die Bedeutung der industrienahen Dienstleistungen in Baden-Württemberg unter besonderer Berücksichtigung der Digitalisierung. Available online: http://www.iaw.edu/tl_files/dokumente/20190117_Endbericht_IndDLBW_final.pdf (accessed on 4 November 2019).

53. Federal Institute for Research on Building, Urban Affairs and Spatial Development (BBSR). Laufende Stadtbeobachtung-Raumabgrenzungen. Stadt-und Gemeindetypen in Deutschland. Available online: https://www.bbsr.bund.de/BBSR/DE/Raumbeobachtung/Raumabgrenzungen/deutschland/ gemeinden/StStadtGemeindet/StadtGemeindetyp_node.html (accessed on 1 November 2019).

54. Kloostermann, R.C.; Lambregts, B. Clustering of Economic Activities in Polycentric Urban Regions: The Case of the Randstadt. Urban Stud. 2001, 38, 717-732. [CrossRef]

55. Meijers, E. Polycentric Urban Regions and the Quest for Synergy: Is a Network of Cities More than the Sum of its Parts? Urban Stud. 2005, 42, 765-781. [CrossRef]

56. Meijers, E.; Hoogerbrugge, M.; Cardoso, R. Beyond Polycentricity: Does stronger integration between cities in polycentric urban regions improve performance? Tijdschr. Voor Econ. Soc. Geogr. 2018, 109, 1-21. [CrossRef]

57. Available online: www.region-stuttgart.de (accessed on 10 November 2019).

58. Federal Employment Agency/Bundesagentur für Arbeit (FEA). (BA): Band 1: Systematischer und alphabetischer Teil mit Erläuterungen. Klassifikation der Berufe. 2010. Available online: https: //www.arbeitsagentur.de/datei/Klassifikation-der-Berufe_ba017989.pdf (accessed on 25 November 2019).

59. Legler, H.; Frietsch, R. Neuabgrenzung der Wissenswirtschaft. In Forschungsintensive Industrien und wissensintensive Dienstleistungen; Studien zum deutschen Innovationssystem: Berlin, Germany, 2006.

60. Krätke, S. Europas Stadtsystem zwischen Metropolisierung und Globalisierung. In Profile und Entwicklungspfade der Großstadtregionen Europas im Strukturwandel zur wissensintensiven Wirtschaft; LIT-Verlag: Berlin, Germany, 2007.

61. Thierstein, A.; Förster, A.; Lüthi, S. Kreativwirtschaft und Metropolregionen-Konturen einer systemischen Steuerung. In Governance der Kreativwirtschaft. Diagnosen und Handlungsoptionen; Lange, B., Kalandides, A., Stöber, B., Wellmann, I., Eds.; transcript Verlag: Bielefeld, Germany, 2009; pp. 61-85.

62. Hall, A. Tätigkeiten und berufliche Anforderungen in wissensintensiven Berufen. In Empirische Befunde auf Basis der BIBB/BAuA-Erwerbstätigenbefragung 2006; Studien zum deutschen Innovationssystem: Berlin, Germany, 2007.

63. Muller, E.; Zenker, A. Business services as actors of knowledge transformation: The role of KIBS in regional and national innovation systems. Res. Policy 2001, 30, 1501-1516. [CrossRef]

64. Consoli, D.; Elche-Hortelano, D. Variety in knowledge base of Knowledge Intensive Business Services. Res. Policy 2010, 39, 1303-1310. [CrossRef]

65. Wiig, A.H.; Isaksen, A. New perspecitves on knowledge of intensive services and innovation. Geogr. Ann. Ser. BHum. Geogr. 2007, 89, 45-58. 
66. Strambach, S. Knowledge Dynamics and Knowledge Commodification of KIBS in Time and Space. In Exploring Knowledge Intensive Business Services; Di Maria, E., Grandinetti, R., Di Bernardo, R., Eds.; Palgrave Macmillan: London, UK, 2012.

67. Pina, K.; Tether, B.S. Towards understanding variety in knowledge intensive business services by distinguishing their knowledge base. Res. Policy 2016, 45, 401-413. [CrossRef]

68. Smith, K.H. What Is the "Knowledge Economy"? Knowledge Intensity and Distributed Knowledge Bases. Ph.D. Thesis, University of Tasmania, Hobart, Australia, 2012.

69. Growe, A. Human capital in the German urban system-Patterns of concentration and specialization. Eur. J. Spat. Dev. 2010, 40, 1-23.

70. Strambach, S. Knowledge-Intensive Business Services (KIBS) as drivers of multilevel knowledge dynamics. Int. J. Serv. Technol. Manag. 2008, 10, 152-174. [CrossRef]

71. Brake, K. Warum nur arbeiten Kreative so gerne in der Stadt? Plan. Rev. 2015, 51, 16-28. [CrossRef]

(C) 2019 by the authors. Licensee MDPI, Basel, Switzerland. This article is an open access article distributed under the terms and conditions of the Creative Commons Attribution (CC BY) license (http://creativecommons.org/licenses/by/4.0/). 